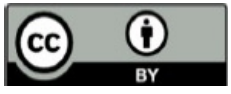

\title{
Verbal-Performance Activities for Optimizing Foreign Language Education
}

\author{
Gergana Dyankova ${ }^{1 *}$, Maya Mladenova² $^{2}$ \\ ${ }^{1}$ Faculty of Pedagogy, South-West Unversity “Neofit Rilski”, Blagoevgrad, Bulgaria, e-mail: diankova_g@swu.bg \\ ${ }^{2}$ Independent scholar, Sofia, Bulgaria, e-mail: mayaadj@yahoo.com
}

\begin{abstract}
The modern world, characterized by dynamic changes, rapid development of ICT and globalization processes sets new challenges to present-day education. This research aims at investigating the influence of applying verbalperformance activities in foreign language education. A pedagogical experiment was conducted in authentic environment with the participation of 99 pupils aged 10 to 11 who formed an experimental and a control group. The study combined qualitative and quantitative approach. It measured pupils' entry and exit levels of practical English knowledge and communicative skills and also traced the effect of the experimental education on the pupils from the experimental group. The interpretative analyses of the results revealed that applying verbal-performance activities in foreign language education led to higher achievements in terms of knowledge and communicative competence for the pupils from the experimental group compared to the progress of the children from the control group. A measurement of the attitude of the pupils from the experimental group towards applying verbal-performance activities in the educational process proved the potential of the method to increase children's motivation for learning. The findings of this research confirm the need of further studies on the influence of applying verbal-performance activities in a broader context of school education.
\end{abstract}

Keywords: verbal-performance activities, foreign language education, communicative skills, motivation for learning.

\section{Introduction}

The modern world of the $21^{\text {st }}$ Century is characterized by rapid changes and fast development. Being successful within present-day reality regarding both professional and personal realization necessitates mastering a variety of skills. While the ability to navigate and draw from complex information remains continuously important to civic participation and personal success, the contemporary environment of social media and web proliferation poses new challenges to competencies such as information literacy (Bonnet, Herakova, and Deng, 2019; Herakova, Bonnet, and Congdon Jr., 2017). In the context of globalization and wide spread of ICT the individual is exposed to a large amount of information and contacts with people from all over the world on a daily basis. "The globalizing world sets new schemes of relationships and manifests itself through ubiquitous interconnection between people, groups, social formations as well as the involvement of the individual within them" (Dyankova, 2019a: 711).

This situation sets a lot of challenges to the whole educational sector which holds major responsibility for preparing young people to interact with the surrounding reality successfully. The traditional way of transferring knowledge from adults to children is no longer effective; the development of ICT is "changing the mechanisms of human socialization and acculturation in the present" which determines the key importance of the reorganization of the educational process (Stošić, Dermendzhieva, and Tomczuk, 2020: 129). Furthermore, the role of the modern teacher "is crucial to stimulate, to facilitate the variety of learning activities in which students analyze the links between the facts and conceptualize new knowledge" (Dyankova, 2018: 9). The educational environment of present-day needs to be based on sharing, comparison and debate which "provide the conditions for maximum personalization of the learning process by transforming the traditional transmission process of educational communication into an organic and authentic dialogue" (Dyankova, 2018: 13). In this regard, the communicative skills of the teacher are of major importance to the successful interaction with pupils as they determine the quality of social relations which "are at the heart of the development of children" (Dermendzhieva, 2019: 114). Communicative competence also enables teachers to "develop strategies to respond to the unpredictability and insecurity caused by rapid changes in society as a whole in family life in the 21 st century" (Dermendzhieva, 2019: 117). All in all, the professional skills of the modern teacher extend far beyond transmitting knowledge because "education in the future is not just about teaching people, but

*Corresponding author: diankova_g@swu.bg 
also about helping them develop a reliable compass to navigate an increasingly complex, ambiguous, and volatile world" (OECD, 2020: 5).

Foreign language education is of major significance to the future social and professional integration of young children. In Bulgaria, it is a compulsory subject throughout primary, secondary and high school level. The main goal of studying a foreign language (English being the most common) is to enlarge pupils' access to information in the context of modern age and to enable them to interact with people from other cultures in the context of globalization. Unfortunately, the average level of practical knowledge which most children acquire within the school system turns out to be relatively low. The reasons for that negative tendency are different but three types of problems seem to be the most common: high difficulty of the subject, low motivation and different levels of knowledge among pupils.

The aforementioned issues need to be addressed by applying experimental methods in the educational process. The current work investigates the influence of verbal-performance activities on pupils' progress regarding English knowledge, communicative skills and motivation for learning. Applying art activities in class is at the center of research of many pedagogical experiments and their findings prove it to be a very successful teaching practice.

Verbal-performance art is a specific artistic form which originates in theatre art. It deals with the stage interpretation of lyrical and epic works and is based on speech as a major means of expression. Verbal-performance art "applies the principles of conditionality and efficiency, which are reflected in the conduct of an active, logical, consistent and organic action in a conditional reality which aims to achieve a particular effect on the perceiver" (Dyankova and Mladenova, 2018: 286).

Verbal-performance activities include all types of tasks which are related to the analysis and interpretation of text materials. They may be completed individually, in pairs, or in small groups. Stage improvisations of texts, based on action instructions, are also regarded as verbal-performance activities despite the lack of a concrete lyrical or epic work. Fulfilling the following conditions is an essential prerequisite for the effective work of applying verbal-performance activities in class: creating an appropriate working atmosphere for verbal-performance activity and motivation for involvement in the interpretation tasks; active sharing of situations from children's everyday life; spontaneous discussions; and providing an equal and fair chance in the process of pupils' participation in the concrete activities (Dyankova, 2019b: 151).

The reasons behind choosing verbal-performance activities as an experimental teaching method in foreign language education are found in their specificity. First of all, they are extremely attractive to young children who love role-playing and performing in front of audience. Secondly, they put the child into an active position and facilitate the process of "learning through experience". Furthermore, verbalperformance activities suppose a high level of interaction both with the teacher and the other pupils and thus encourage the process of "learning from each other". Last but not least they predispose the manifestation of children's creativity which is essential to their overall development.

Another major advantage in favour of applying verbal-performance activities is the similarity between the objectives of foreign language education and practicing verbal-performance art. Both are aimed at improving children's communicative skills. What is more, they both rely on work with text materials and include reading, listening and speaking activities.

The vital importance of developing young learners' communicative competence is indisputable. Communicative competence can be defined as a set of skills that facilitate "critical engagement with people, communities, and messages" (Herakova, Bonnet, and Congdon Jr., 2017: 110). It is a type of competence which determines the successful interaction of the individual with the surrounding reality to a great extent. The significance of assertiveness for "the effectiveness of interpersonal relationships" is thoroughly studied by the psychologists Peneva and Mavrodiev who point out that it demands the absorption of certain skills; "the ability to speak openly about own feelings and desires" being one of the most important among them (Peneva, and Mavrodiev, 2013: 7). Communication is the base of socialization, effective learning, professional realization, acculturation etc. Yet, it is not taught as a subject at school despite the fact that "every single detail of the pedagogical interaction in the school institution is required to construct a phenomenally comprehensive lesson in communication" (Dyankova and Mladenova, 2018: 281). In spite of the mass distribution and active use of ICT in our lives, people from the present-day world seem to face more alienation, isolation and loneliness even within the most basic social union - the family. "The modern family, not only in an economic but also in a deep spiritual crisis, needs both socio-economic and professional-psychological support" (Tasevska, 2008: 12).

In order to address the need of specific pedagogical attention towards the development of children's communicative skills, the current research focuses on creating a separate complex of verbal-performance activities aimed at improving the communicative competence of the pupils. As this competence includes 
a huge variety of skills, only five specific aspects are selected on the base of their significance to foreign language education:

1) Effective listening is a fundamental communicative skill which helps children form relationships with their peers and teachers. It combines the ability to notice the changes in a speaker's verbal performance and to extract meaning out of the observations. Effective listening ensures that children decode their communicative partner's intentions accurately enabling them to understand the other person's point of view better. Furthermore, listening is central to "collaborative and humanizing" dialogue, which "attends to and includes the communication of facts, values, feelings, and beliefs" (Congdon Jr., Herakova, and Bishop, 2018: 9). Regarding foreign language education, this skill is especially important as acquiring meaningful information via paralinguistic aspects of speech facilitates the process of understanding people who use unfamiliar vocabulary. Advanced listening skills condition the development of other important social skills, such as team work, problem-solving, conflict resolution, information literacy etc.

2) Formulating and pursuing a communicative purpose is a skill which helps pupils control their communicative behaviour and create a desired impact on their partners. It is of basic significance to young learners who tend to let their momentary emotions take over and show during a conversation which might lead to misunderstanding and unwanted results of the interaction. The skill consists of the ability to formulate a clear purpose based on one active verb and put the proper amount of energy when pursuing it. "To speak means to act. Precisely this activity prompts the task to inculcate our ideas into others" (Stanislavski, 1982: 95). If the formulation of the purpose is ambiguous or based on more than one verb, the speaker will get confused trying to achieve more than one result at the same time. Putting the proper amount of energy in the process of pursuing the purpose ensures the effective outcome of the conversation.

3) Mastering body language is a skill related to the ability to control physical expression and to consciously use body's signals to reveal an individual's intentions in a clear and vivid way. Although non-verbal, body language is highly expressive and mastering it ensures more effective interaction with others. Being visible, body language signals might prove extremely distracting for the listener when not appropriate. Furthermore, it is closely interrelated with verbal action which means that it is practically impossible to carry out even the simplest spoken task effectively without supporting it with relevant physical behaviour. In terms of foreign language education, being in a good control of their body signals enables pupils to develop additional communicative strategies which relieve the language barrier frustration and help them express their intentions even using only basic vocabulary knowledge.

4) Speech expressiveness is an important communicative skill related to masterful use of the paralinguistic aspects of speech, such as intonation, volume, speed, stress, pause in order to reveal the logical and emotional aspects of an individual's verbal manifestation. The paralinguistic features are highly communicative and add meaning to the text we articulate. The level of impact of speech depends not only on the speaker's conviction in his/her ideas but also on "the speech perfection via which he/she connects to the perceiver" (Penchev, 1991: 5). Although Laan highlights the complex differentiation of intonation in reading aloud and speaking spontaneously (Laan, 1997), the specifics of intonation are successfully identified by Lowry (Lowry, 2002) and Cruttenden (Cruttenden, 2007). In addition Hudson, Lane, and Pullen distinguish the basic significance of speech's smoothness as a quality of verbal manifestation (Hudson, Lane, and Pullen, 2005). Skillful use of intonation, volume and rhythm provides children with a greater scope of emotional expression and helps them reveal their inner desires and intentions clearly and vividly. Thus their messages have a bigger chance to be successfully delivered to the listeners. "To speak means to draw visual images" which arise in the perceiver's mind (Stanislavski, 1982: 91). In terms of teaching English, Markus points out the importance of intonation and the need to encourage pupils to master its standard styles (British and American), rather than use a markedly deviant variety derived from their native language (Markus, 2008). In combination with advanced body language expression, the ability to "code" our verbal expression via paralinguistic channels of information facilitates the process of communicating in English. This fact is supported by Wennerstrom's research which confirms that "the emotional function of intonation is not language-specific, but can instead be a resource in cross-cultural communication" (Wennerstrom, 2001: 1183).

5) Conflict resolution is a skill of major importance which is related to handling conflict situations in a positive way. Conflicts are usually unpleasant to experience due to negative emotions and identity threats that people may experience when faced with opposing ideas (Congdon Jr., Herakova, and Bishop, 2018). Yet, becoming involved in numerous communicative situations every day and interacting with various partners makes conflicts inevitable. The skill of conflict resolution includes mastering techniques for adapting to the partner and strategies to react in a conflict situation. In terms of educational environment it is a vital ability considering the high levels of aggressive behaviour which characterizes pupils' informal 
interactions. If children achieve a high level of awareness about the dynamics of partner - situation, they would be able to make more effective choices of communicative strategies. Consequently, the outcome of the conflict situation might be positive - new ideas might be conceived and implemented, pupils' mindset can be broadened and even relationships may be deepened. Because of this complexity and its embodied character, conflict resolution is best learned not through cognitive transmission of knowledge, but through performed actions, as Congdon Jr., Herakova, and Bishop (2018) demonstrated with their teaching activity, using Boal's Forum Theater technique. Practicing conflict resolution through role-play, students reported that the activity taught them to communicate "with more empathy and understanding and has allowed them to try out communication strategies" (Congdon Jr., Herakova, and Bishop, 2018: 11), such as using "I-language" and focusing on observing and describing the situation instead of blindly reacting to it.

The development of the aforementioned aspects of communication competence via verbalperformance activities is only the starting phase of an ongoing, more thorough research. It is going to cover a more extended period of time which is needed in order to study the subject profoundly.

\section{Materials and Methods}

The main method of this research is a pedagogical experiment which was carried out in authentic environment. It took place in Secondary school "D-r Petar Beron" - Kostinbrod, Bulgaria and included 99 pupils aged 10 to 11. The main purpose of the study was to develop a system of verbal-performance activities which optimize foreign language education. The subject of the research was the process of enhancing pupils' level of knowledge and communicative skills through applying verbal-performance activities in class. An additional task of the study was to measure the attitude of the participants towards the experimental education and especially its impact on their motivation for learning.

The pedagogical experiment was implemented through both regular curricular lessons in English and extracurricular activities, such as clubs of interest and summer school projects. The participating students were divided in two groups: experimental group (48 children) and control group (51 children). Each group consisted of two classes.

The study was conducted in three stages: an ascertaining experiment to define the entry level of knowledge and communicative skills of both the experimental and control group; a formative experiment where the pupils from the experimental group were taught by applying the developed system of verbalperformance activities into the educational process; and control experiment to check the exit knowledge and communicative skills results of both groups. The research was carried out within the period 2018 2019. The experimental education was realized through the following forms of work: individual, in pairs and in groups.

The study combined quantitative and qualitative approach. The methods of collecting data included testing, expert evaluation and structured interviewing. Special diagnostic and exit tests were designed to check the level of English knowledge. They were focused on those parts of the learning material which were influenced by the experimental education. A criteria matrix was created in order to assess the selected specific aspects of pupils' communicative skills. The expert evaluation was implemented by two verbal communication specialists using individual records for each pupil. The impact of the experimental education on pupils' motivation for learning was measured by questionnaires which included both closed and opened questions. 
Table 1

A criteria matrix for evaluating aspects of pupils' communicative skills

\begin{tabular}{|c|c|c|c|c|c|}
\hline Criterion & 0 points & 1 point & 2 points & 3 points & 4 points \\
\hline $\begin{array}{l}\text { 1. Effective } \\
\text { listening }\end{array}$ & $\begin{array}{l}\text { Doesn't listen; can't } \\
\text { decode the } \\
\text { information }\end{array}$ & $\begin{array}{l}\text { Listens indifferently; } \\
\text { decodes the information } \\
\text { wrongly }\end{array}$ & $\begin{array}{l}\text { Listens carefully; } \\
\text { decodes the information } \\
\text { roughly }\end{array}$ & $\begin{array}{l}\text { Listens carefully; } \\
\text { decodes the } \\
\text { information correctly } \\
\text { without nuances }\end{array}$ & $\begin{array}{l}\text { Listens attentively; } \\
\text { decodes the } \\
\text { information } \\
\text { correctly with } \\
\text { nuances }\end{array}$ \\
\hline $\begin{array}{l}\text { 2. Communicative } \\
\text { purpose }\end{array}$ & $\begin{array}{l}\text { Can't formulate a } \\
\text { purpose; doesn't } \\
\text { pursue one }\end{array}$ & $\begin{array}{l}\text { Formulates an ambiguous } \\
\text { purpose based on several } \\
\text { verbs; doesn't pursue it } \\
\text { actively }\end{array}$ & $\begin{array}{l}\text { Formulates a clear } \\
\text { purpose based on one } \\
\text { inactive verb; doesn't } \\
\text { pursue it actively }\end{array}$ & $\begin{array}{l}\text { Formulates a clear } \\
\text { purpose based on one } \\
\text { active verb; doesn't } \\
\text { pursue it actively } \\
\text { enough }\end{array}$ & $\begin{array}{l}\text { Formulates a clear } \\
\text { purpose based on } \\
\text { one active verb; } \\
\text { pursues it actively }\end{array}$ \\
\hline 3. Body language & $\begin{array}{l}\text { Inappropriate pose; } \\
\text { makes distracting } \\
\text { gestures all the time }\end{array}$ & $\begin{array}{l}\text { Unstable and inexpres- } \\
\text { sive pose; makes dis- } \\
\text { tracting gestures most of } \\
\text { the time }\end{array}$ & $\begin{array}{l}\text { Stable but inexpressive } \\
\text { pose, makes distracting } \\
\text { gestures from time to } \\
\text { time }\end{array}$ & $\begin{array}{l}\text { Stable and expressive } \\
\text { pose; doesn't make } \\
\text { distracting gestures }\end{array}$ & $\begin{array}{l}\text { Stable and } \\
\text { expressive pose; } \\
\text { the gestures } \\
\text { support the } \\
\text { communicative } \\
\text { purpose }\end{array}$ \\
\hline $\begin{array}{l}\text { 4. Speech } \\
\text { expressiveness }\end{array}$ & $\begin{array}{l}\text { The speech is } \\
\text { monotonous and } \\
\text { inexpressive all the } \\
\text { time }\end{array}$ & $\begin{array}{l}\text { The speech is } \\
\text { monotonous and inex- } \\
\text { pressive most of the time }\end{array}$ & $\begin{array}{l}\text { The speech is varied } \\
\text { and expressive half of } \\
\text { the time }\end{array}$ & $\begin{array}{l}\text { The speech is varied } \\
\text { and expressive most } \\
\text { of the time }\end{array}$ & $\begin{array}{l}\text { The speech is } \\
\text { varied and } \\
\text { expressive all the } \\
\text { time }\end{array}$ \\
\hline $\begin{array}{l}\text { 5. Conflict } \\
\text { resolution }\end{array}$ & $\begin{array}{l}\text { Unable to adapt to } \\
\text { the partner; } \\
\text { communicates } \\
\text { aggressively all the } \\
\text { time }\end{array}$ & $\begin{array}{l}\text { Slightly adapts to the } \\
\text { partner; communicates } \\
\text { aggressively from time to } \\
\text { time }\end{array}$ & $\begin{array}{l}\text { Adapts to the partner to } \\
\text { a certain extent; } \\
\text { communicates politely } \\
\text { but without } \\
\text { understanding }\end{array}$ & $\begin{array}{l}\text { Adapts to the partner } \\
\text { to a great extent; } \\
\text { communicates politely } \\
\text { with understanding }\end{array}$ & $\begin{array}{l}\text { Adapts to the } \\
\text { partner effectively; } \\
\text { communicates } \\
\text { politely with } \\
\text { empathy and } \\
\text { understanding }\end{array}$ \\
\hline
\end{tabular}

The numerical data, which was obtained as a result of the research, was systematized in tables and graphs. It was subjected to mathematical-statistical treatment which became the base for interpretative analyses.

Due to the specificity of verbal-performance activities the experimental work focused on three of the four learning cores regarding English knowledge: reading comprehension, listening comprehension and speaking skills. For the same reason the research was aimed at mastering new vocabulary rather than grammar. Suitable text materials which were relevant to the level of knowledge were chosen to be used in the teaching process. The study also covered five vocabulary topics included in the curriculum. Futhermore a complex of verbal-performing activities was constructed in order to achieve the objectives of the pedagogical experiment. A part of that complex was purposely designed so as to improve the communicative skills of the pupils in accordance with the criteria matrix.

The experimental education included three types of lessons: work with text materials aimed at extracting, analyzing and summarizing information from a text; listening and speaking tasks aimed at mastering new vocabulary on a certain topic; and work on improvised situations aimed at enhancing pupils' communicative skills. Those three types of lessons were alternated throughout the whole study. Following next, a detailed description of example verbal-performance activities assigned to each task is provided. The authors plan to publish the whole complex as a supporting teaching resource.

Type 1 lessons: work with text materials. In order to complete the tasks, each pupil is provided with a glossary for each text. The materials were retrieved from online teaching resources.

Task 1. A monologue story. "The Wolf's Tale" by Louise Cooper tells the popular fairy tale of Little Red Riding Hood through the eyes of the wolf who happens to be the grandmother cursed to become a werewolf (Cooper, 2002).

Example verbal-performance activity: The pupils from each team construct and rehearse a short court process "People against the Grandmother-werewolf". They have to present the conviction and the defense of the creature in front of the others who determine the result of the process by voting "guilty" or "not guilty". 
Task 2. A short story. "The Pet Shop" is a story about a brother and a sister who want to buy a dog but argue over the choice between two dogs (The Pet Shop). They agree on a running race where the winner chooses the dog. The brother cheats at the beginning of the race and wins but when they go back to the pet shop, it turns out his dog has been sold and they end up buying the dog - Teacup - which was the girl's choice.

Example verbal-performance activity: The pupils from each team invent and rehearse a short interview with the dog Teacup on the local Animal TV where the Chihuahua shares its feelings about the events in the story. They play the interview in front of the others who decide if the most relevant information from the text is included in it.

Task 3. A poem. "Two little kittens" after an unknown author follows the story of two kittens fighting over a mouse (Two little kittens, 1879). The old lady in the house sweeps them out in the cold where they stay for some time. When the lady lets them back in, the kittens have realized that it is much better to be meek and quiet.

Example verbal-performance activity: The children from each team have to transform the story in a short play showing similar events which happen between children and a parent/teacher instead of kittens and an old woman. They act out the play in front of the others who decide whether it corresponds to the poem's plot. (Aesop).

Task 4. A fable. Aesop's famous fable "The Ant and the Grasshopper" is used as a text material

Example verbal-performance activity: The pupils from each team create and rehearse a short monologue version of the fable from the point of view of one of its characters. They present the monologues in front of the others who have to decide what attitude the performances provoke towards each of the characters.

Type 2 lessons: mastering new vocabulary. In order to complete the tasks, each pupil is provided with a set of about fifteen new words on each topic.

Task 1. Vocabulary topic "Fashion" - types of clothes, materials, colours, patterns.

Example verbal-performance activity: The class is provided with a set of pictures showing people wearing different clothes of various materials, patterns and colours. In teams, the children have to act out a fashion review with speakers and models. The speakers pick up a picture with clothes which they describe to the audience while the model who is presenting the outfit has to show and express attitude towards the imaginary pieces of clothing. The spectators are encouraged to react to the review and vote for their favorite outfit in the end. weather.

Task 2. Vocabulary topic "Tourism" - geographical features, ways to travel, holiday activities,

Example verbal-performance activity: Individually, in pairs or in teams, pupils prepare an advertising presentation of a chosen holiday destination. Performing the role of tour guides, they try to convince the audience that their offer is the best. The other children have to choose the most convincing performance by voting.

Task 3. Topic "Animals" - pets, wild animals, parts on animal bodies.

Example verbal-performance activity: In pairs or in groups, the children have to create a sketch on the topic "At the zoo". The teacher provides basic instructions but also encourages them to use their own ideas. The example instruction is for an enthusiastic zookeeper who walks two visitors around - one of them curious and absent-minded, the other - cautious and anxious. Conflicts, hysteria and chaos arise when they reach the section "extremely dangerous animals". Pupils from the team can play some of the animals, too. After the performance, the other children have to explain what happened.

Task 4. Topic "Music" - instruments, musicians, music activities, music genres.

Example verbal-performance activity: In pairs, the children have to construct and rehearse an interview with a music star (preferably their own favourite musician). They perform the interview in front of the others who have to vote for the most interesting interview.

Task 5. Topic "Cooking" - food, cooking activities, tastes.

Example verbal-performance activity: In pairs, the children have to create and act out a cooking show playing the roles of a bossy, impatient master chef and a cheerful, clumsy assistant cook. They present the process of preparing a traditional local dish while fighting all the time. The others have to select the best presented recipe. 
Type 3 lessons: work on improvised situations.

Task 1. Mastering effective listening.

Example verbal-performance activity: The pupils are provided with a short dialogue between two children who meet in the schoolyard. Three pairs of students are provided with three different sets of instructions about the attitudes and feelings of the two characters. An example instruction is of classmates - A despises $B$ and feels bored while $B$ admires $A$ and feels excited. Each pair performs their version of the dialogue and following each performance the other pupils have to describe the attitudes and feelings of the characters. They try to motivate their answers with concrete observations of the performers' communicative behaviour.

Task 2. Formulating and pursuing a communicative purpose.

Example verbal-performance activity: Children are provided with several example sentences. Each pupil picks up one sentence and has to formulate five different communicative purposes he/she wants to achieve via it. Each child performs their sentence five times pursuing one of the formulated purposes at a time. The other students have to guess them. An example sentence is "I am extremely glad that everybody is here." An example model of a communicative purpose is "I want to prepare you for good news."

Task 3. Mastering body language techniques.

Example verbal-performance activity: Each pupil is provided with a short written message and has to "enter" and deliver it to the audience using only body language. The other children have to guess the message. An example message says "The principal is coming down the corridor - you have to make everybody stay quiet until he goes away because he shouldn't understand you are here."

Task 4. Articulating emotions through speech expressiveness.

Example verbal-performance activity: Each pupil picks up a sheet of paper with a different emotion written on it. He/she has to express that emotion via a provided sentence. The sentence is repeated four times and each time the emotion is stronger. The fifth time the sentence is transformed into non-existing language and the emotion is expressed only through the paralinguistic aspects of speech. The other children have to guess the emotion. They are encouraged to react to each repetition of the sentence and thus help the performer become more and more expressive. An example sentence is "You have got to be kidding me!" and example emotions are: bored, angry, surprised, hopeful, confused, happy, scared etc.

Task 5. Conflict resolution.

Example verbal-performance activity: In pairs, the pupils create and perform a conflict dialogue with a disastrous end. Short instructions on the situation and characters can be provided, for example a parent and a child argue over the child's desire to go to a rock concert with a friend and the parent's refusal to give permission. After the performance the other children have to analyze the feelings of both characters and the reasons for their negative behaviour. Then they think of an alternative way to act out the conflict situation so that it gets resolved in a better way.

\section{Results}

The last part of the pedagogical experiment included summarizing and analyzing the data collected within its implementation.

The purpose of measuring the entry and exit levels of English knowledge of both the experimental and control group was to compare the outcomes of the experimental and traditional teaching processes. For the sake of convenience, the average numerical values were transformed into percentage and presented in Chart 1.

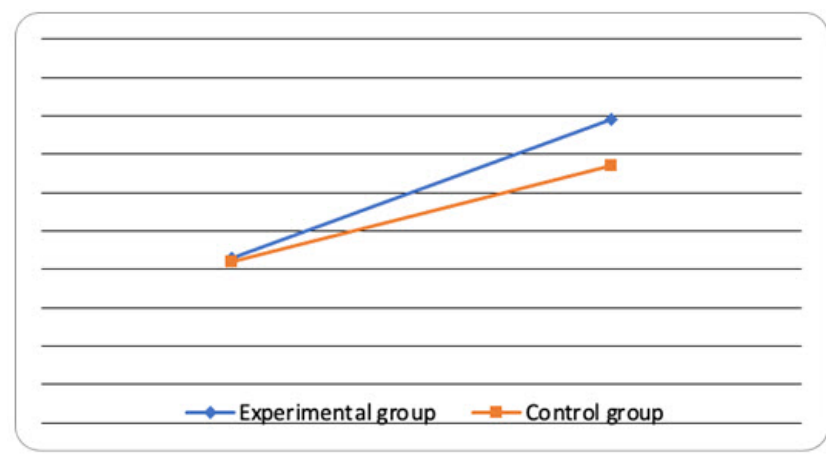

Chart 1. Comparison of the average values of practical English knowledge of the experimental and control groups. 
The comparison of the results clearly showed that the exit level achieved by the pupils of the experimental group was significantly higher $(79 \%)$ than that of the control group (67\%) considering the fact that the entry levels were relatively close $(43 \%$ and $42 \%)$. An analysis of the values for each child revealed that a $100 \%$ of the experimental group achieved individual progress on their knowledge while $14 \%$ of the control group didn't show any advancement. These highlighted facts led to the conclusion that the experimental education based on verbal-performance activities affected positively the process of mastering English knowledge by the pupils involved in it.

The assessment of the entry and exit levels of the children's communicative skills in accordance with the criteria matrix showed similar results. Each student from both groups received an overall numerical mark which was the sum of his/her points for each criterion. Those marks were transformed into percentage and their average values are presented in Chart 2.

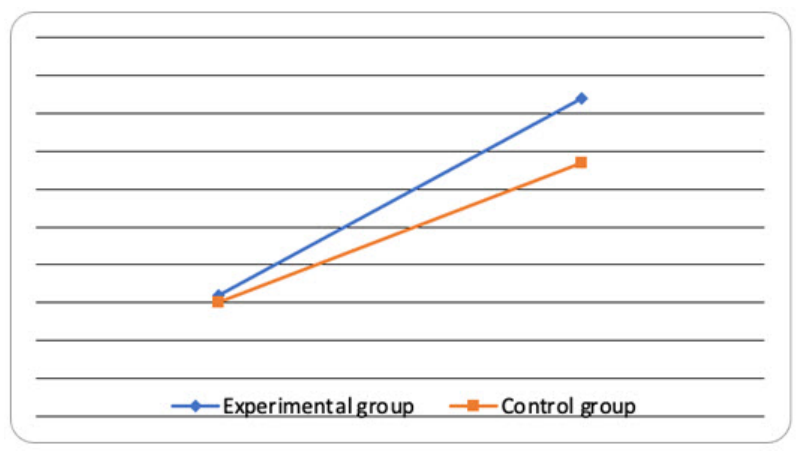

Chart 2. Comparison of the average values of communicative skills of the experimental and control groups.

The entry level results of the experimental and control groups were respectively $32 \%$ and $30 \%$, i.e. there was no significant difference between the average values. However, the exit level results showed that the average value of the experimental group $(84 \%)$ was considerably higher than that of the control group $(67 \%)$. An analysis of the individual results revealed that $100 \%$ of the children in both groups achieved progress but among the control group there was not a result higher than $72 \%$ while the highest result achieved in the experimental group was $95 \%$. On the base of these findings, the research team drew the conclusion that applying the complex of verbal-performance activities led to higher development of the communicative skills of the children in the experimental group compared to that of the control group.

The personal attitude of the pupils from the experimental group towards the experimental education was measured with questionnaires. The closed questions used statements and a rating scale. The distributions of the respondents' opinion, which were indicated, are presented in Table 2.

Table 2

Distributions of the experimental group's attitudes towards the experimental education

\begin{tabular}{lccccc}
\hline \multicolumn{1}{c}{ Statement } & Strongly agree & Agree & Neutral & Disagree & Strongly disagree \\
\hline 1.I had fun during the experimental education & $79 \%$ & $21 \%$ & $0 \%$ & $0 \%$ & $0 \%$ \\
2. I feel more confident about my English knowledge & $90 \%$ & $0 \%$ & $10 \%$ & $0 \%$ & $0 \%$ \\
3. My personal motivation to study English increased & $86 \%$ & $10 \%$ & $0 \%$ & $4 \%$ & $0 \%$ \\
\hline
\end{tabular}

The results from the closed questions clearly showed that most of the pupils ( $90 \%$ and above) considered the experimental education fun and agreed that it increased their motivation and confidence. The analysis of the answers to the open questions revealed an almost identical attitude. The most common tendencies found in pupils' statements were that they had great time during the experimental education; they wanted to participate in it again; they enlarged their English knowledge; and they registered development of their communicative skills. The children's attitude led to the conclusion that applying verbal-performance activities in foreign language education increases their motivation for learning.

\section{Discussions and Conclusions}

The results from the current experiment clearly outline the educational potential of verbalperformance activities as a teaching method. The interconnections between communicative competence 
development and verbal-performance practices determine the significance of applying such methods in a broader context of school education. Based on the experiment's positive outcomes and attitude of the participating pupils, the following conclusions are derived:

1) Verbal-performance activities have the potential to optimize other school subjects from the curriculum, especially in the humanitarian field. All subjects which rely on reading and use of text materials can benefit from applying the method. It will help teachers organize their lessons in accordance with the principle of "learner-centered" education.

2) Applying verbal-performance activities can address some of the most alarming problems within Bulgarian educational system - the low levels of literacy, functional literacy and information literacy among Bulgarian pupils. Interaction with texts and information on analytical level will help children train all the mental skills needed to improve those fundamental competences.

3) Developing a broader range of aspects of communicative skills via verbal-performance activities can influence positively children's social integration and acculturation. Analyzing and understanding different ideas, values and points of view through effective communication will build up tolerance and empathy. This process will not only improve class atmosphere, but it is also crucial in terms of multicultural educational environment - a phenomenon which is more and more common.

4) Applying verbal-performance activities is a powerful means to increase pupils' motivation for learning and it provides the chance to be combined with other successful practices, such as introducing ICT in education. Children spend most of their time using ICT and the process of completing attractive learning tasks with the help of their favourite devices or sharing and discussing their achievements via social media will enhance their motivation for learning significantly. "The new generation of kids comes ready to work with these new technologies, which play an important role in children's learning and acquiring various cognitive knowledge so that educational technology must be incorporated into future curricula" (Stošić, 2015: 113).

The findings of this study suggest that further research on the benefits of applying verbal-performance activities in school education has the potential to provide modern teachers with new teaching methods which will enable them to meet the challenges of present-day educational process more successfully.

\section{Acknowledgments}

The research is conducted with the organizational support of Secondary school "D-t Petar Beron", Kostinbrod, Bulgaria.

Dr. Liliana Herakova, Assistant Professor from the Department on Communication and Journalism, University of Maine, Orono, USA provided assistance in implementing a part of the experimental education tasks.

\section{Conflict of interests}

The authors declare no conflict of interest.

\section{References}

Aesop. The travelers and the bear. Retrieved June, 1, 2018, from https://www.artsonthemove.co.uk/resources/aesop-s-fables. php

Bonnet, J. L., Herakova, L., \& Deng, R. (2019, April). Setting the stage for civic-minded education: Casting new roles for librarians in critical information literacy instruction. In Recasting the narrative: The proceedings of the ACRL 2019 Conference, Edited by Dawn M. Mueller. Retrieved from http://www.ala.org/acrl/sites/ala.org.acrl/files/content/ conferences/confsandpreconfs/2019/SettingtheStageforCivic-MindedEducation.pdf

Congdon, M., Herakova, L., \& Bishop, J. (2018). Calling-in the family: Dialogic performances of family conflict. Communication Teacher, 32(1), 8-12. https://doi.org/10.1080/17404622.2017.1372614

Cooper, L., (2002). The Wolf's Tale. Short and Scary. Oxford University Press. Retrieved from http://www.teachingenglish.org. uk/article/wolfs-tale

Cruttenden, A. (2007). Intonational diglossia: a case study of Glasgow. Journal of the International Phonetic Association 37(2), 257-274. https://doi.org/10.1017/S0025100307002915

Dermendzhieva, S. (2019). Studying the welfare of children at an early age in the system of institutional care. International Journal of Cognitive Research in Science, Engineering and Education (IJCRSEE), 7(1), 95-119. https://doi.org/10.5937/ ijcrsee1901095D

Dyankova, G. (2018). Research of cognitive exchange specifics in teachers academic training. International Journal of Cognitive Research in Science, Engineering and Education (IJCRSEE), 6(3), 1-14. https://doi.org/10.5937/ijcrsee1803001D

Dyankova, G. (2019a). Detskata gradina v konteksta na socialnite posledici ot globalizacionnia process. [Preschool in the context of the social consequences of the globalization process]. Bulgarian Journal of Educational Research and Pedagogy, 
91(5), 711-724. Retrieved from https://pedagogy.azbuki.bg/pedagogics/pedagogyarticle/pedagogyarticle2016-4/ detskata-gradina-v-konteksta-na-soczialnite-poslediczi-ot-globalizaczionniya-proczes/

Dyankova, G. (2019b). Slovesnata deistvenost na uchitelia I prosocionalnoto povedenie na deteto. [Verbal activity of the teacher and the pro-social behaviour of the child]. Veliko Tarnovo: European information center.

Dyankova, G., \& Mladenova, M. (2018). Pedagogical rhetoric - a criterion for mutually effective education. In Education and Quality of Life in the Condition of Transition - Thematic Collection of Papers of International significance. (278-300), University of Pristina, Faculty of Philosophy, Kosovska Mitrovica.

Herakova, L., Bonnet, J., \& Congdon Jr., M. (2017). Centering information literacy (as) skills and civic engagement in the Basic Communication Course: An integrated course library collaboration. Basic Communication Course Annual, 29, Article 12. Retrieved from http://ecommons.udayton.edu/bcca/vol29/iss1/12

Hudson, R. F., Lane, H. B., \& Pullen, P. C. (2005). Reading fluency assessment and instruction: What, why, and how?. The Reading Teacher, 58(8), 702-714. https://doi.org/10.1598/RT.58.8.1

Laan, G. P. (1997). The contribution of intonation, segmental durations, and spectral features to the perception of a spontaneous and a read speaking style. Speech Communication, 22(1), 43-65. https://doi.org/10.1016/S0167-6393(97)00012-5

Lowry, O. (2002). The stylistic variation of nuclear patterns in Belfast English. Journal of the International Phonetic Association, 32(1), 33-42. https://doi.org/10.1017/S0025100302000130

Markus, M. (2008). The relevance of spoken features in English as a foreign language (EFL). English Today, 24(4), 17-25. https://doi.org/10.1017/S0266078408000357

OECD (2020). PISA 2018 Results (Volume VI): Are Students Ready to Thrive in an Interconnected World?, PISA, OECD Publishing, Paris, https://doi.org/10.1787/d5f68679-en

Peneva, I., \& Mavrodiev, S. (2013). A historical approach to assertiveness. Psychological Thought, 6(1), 3-26. https://doi. org/10.5964/psyct.v6i1.14

Penchev, P. (1991). Govorna kultura. [Speech culture]. Blagoevgrad.

Stanislavski, K. S. (1982). Rabotata na aktiora nad sebe si. [The work of the actor on themselves. Part II]. Nauka I izkustvo, Sofia.

Stošić, L., Dermendzhieva, S., \& Tomczuk, L. (2020). Information and communication technologies as a source of education. World Journal on Educational Technology: Current Issues, 12(2), 128-135. https://doi.org/10.18844/wjet.v12i2.4815

Stošić, L., (2015). The importance of educational technology in teaching. International Journal of Cognitive Research in Science, Engineering and Education (IJCRSEE), 3(1), 111-114. Retrieved from https://ijcrsee.com/index.php/ijcrsee/ article/view/76

Tasevska, D. (2008). SOS Semejstva v kriza, psiho - logicheska podkrepa na disfunkcionalni seme - jstva za efektivno roditelstvo. [SOS Families in crisis, psychological support of dysfunctional families for effective parenting]. University Publishing House St. St. Cyril and Methodius, Veliko Tyrnovo.

The Pet Shop. Retrieved June 1, 2018, from https://www.really-learn-english.com/english-short-stories-level-05-story-01.html Two little kittens. (1879) Retrieved June 1, 2018, from https://www.dennydavis.net/poemfiles/travel/catpoem2.htm

Wennerstrom, A. (2001). Intonation and evaluation in oral narratives. Journal of Pragmatics, 33(8), 1183-1206. https://doi. org/10.1016/S0378-2166(00)00061-8 